\title{
Chemical Composition and Antibacterial Effect of Medicinal Plants against Some Food-Borne Pathogens
}

\author{
Hassan Habibi ${ }^{1 *}$, Najmeh Ghahtan ${ }^{2}$, Mohammad Amin Kohanmoo ${ }^{1}$, Fatemeh Eskandari ${ }^{3}$ \\ ${ }^{1}$ Assistant's professor of Agriculture and Natural Resources College, Persian Gulf University, Bushehr, Iran. \\ ${ }^{2}$ Student of horticultural sciences, Faculty of Agriculture and natural resource, Persian Gulf University, Bushehr, Iran. \\ ${ }^{3}$ Bushehr University of Medical Sciences, Bushehr, Iran.
}

\section{Received: 8 Feb 2017}

Revised : 28 Feb 2017

Accepted: 13 Mar 2017

Corresponding Author: Hasan Habibi

Assistant's professor of Agriculture and Natural Resources College, Persian Gulf University, Bushehr, Iran.

Phone: +98-9173034921

E-mail: h.habibi@pgu.ac.ir

\begin{abstract}
Background: Pulicaria gnaphalodes, Ducrosia anethifolia, Trachyspermum copticum, Foeniculum vulgare Mill and Majorana hortensis Minch are widely used as herbal plants in traditional medicine and they have been reported to have a variety of therapeutic effects. This study was carried out to evaluate the antimicrobial effects of essential oils (EOs) extracted from these medicinal herbs against six species of food-borne microorganisms.

Materials and Methods: The EOs were analyzed by gas chromatography mass spectrometry (GC/MS). The detection of inhibitory effect of the EOs on the tested bacteria was carried out by agar disk-diffusion method and then MIC (Minimum Inhibitory Concentration) and MBC (Minimum Bactericidal Concentration) of the EOs against six bacteria were determined.

Results: The analysis of the components of the essential oils (EOs) extracted by gas chromatography spectrometry allowed the identification of 63 compounds of the five tested EOs. All of these five tested EOs indicated an antimicrobial effect against strains of Bacillus sp and Listeria Monocytogenes ATCC1297. Essential oils from T. copticum, M. hortensis and F. vulgare possessed a wide spectrum of antibacterial activity against the growth of the six bacteria with zone diameter of inhibition (ZDI) between 14-32 mm, depending on the susceptibility of the tested organism.

Conclusion: Antibacterial efficacy shown by these plants provides a scientific basis and thus validates their use as medicinal remedies. Isolation and purification of different phytochemicals may further yield significant antibacterial agents.
\end{abstract}

Keywords: Essential oils; Antimicrobial activity; Chemical composition; Medicinal herb

\section{Introduction}

In modern societies, the safety of meat and its products is widely recognized as meat consumption is important for human growth, development and maintenance of health (1). A major issue related to meat consumption is the presence of pathogens and among them the causative agents of food-borne diseases are the leading causes of illness and death (2). Food processors, food safety researchers, and regulatory agencies have been increasingly concerned with the growing number of food-borne illnesses outbreaks caused by the pathogens like
Staphylococcus aureus, Salmonella sp, Clostridium perfringens, Campylobacter, Listeria monocytogenes, Vibrio parahaemolyticus, Bacillus sp, and enteropathogenic Escherichia coli $(1,3)$. These bacteria cause over $90 \%$ of all cases of food poisoning (4). Listeria monocytogenes is a ubiquitous gram-positive pathogen responsible for a serious disease named listeriosis and the overall mortality rate associated with this disease is $30 \%$.

Antibiotic use has been banned in the European Union since January 2006. For this reason, scientists 
have become interested in evaluating other alternatives to control specific microbial populations to modulate rumen fermentation (5). The antibacterial activities of spices and their essential oils have been known for a long time and a number of researches have reported the antibacterial effect of these spices, their essential oils as well as their derivatives (6). Plant essential oils are the potentially useful sources of antimicrobial compounds. Numerous studies have been published on the antimicrobial activities of plant compounds against many different types of microorganisms including food-borne pathogens (7). For a long time, plants from the Apiaceae family have been used as spices or drugs particularly due to their essential oils. A dozen important herbal medicinal products from this botanic family are used in some pharmacopoeias, antiseptic, expectorant, diuretic, carminative, vasodilator or spasmolytic actions (8). The members of this family are well known as vegetables, culinary and medicinal plants such as Foeniculum vulgare, Ducrosia anethifolia Trachyspermum copticum and etc (9).

Majorana hortensis Moench (Syn. Origanum majorana L.), commonly known as 'sweet marjoram', is a perennial aromatic herb of the family Lamiaceae (10). The aerial parts of the plant are used for the isolation of essential oils, which have a lot of uses in the flavor, perfumery and pharmaceutical industries. The essential oils are employed for external application in bruises, sprain, stiffs and paralytic limbs, toothache and as hot fomentation in acute diarrhea. In the food industry, it is mainly used as a spice in sausages but its use in the baked goods, the processed vegetables, condiments, soups, snack foods and gravies is also reported (11).

Pulicaria gnaphalodes (Vent.) Boiss. is an annual herb producing small bright yellow flowers (12). The chemical investigation of the Pulicaria genus has revealed the occurrence of molecules such as diterpenes, sesquiterpenes, caryophyllenes and caryophyllane derivatives and flavonoids (13). Various biological activities have been reported for some species of Pulicaria, such as antibacterial, antifungal and insecticidal properties (14).

The aim of the present study was to determine the chemical composition of some of the most important essential oils extracted from the cultivated plants all around Iran, including Pulicaria gnaphalodes, Ducrosia anethifolia, Trachyspermum copticum, Foeniculum vulgare Mill and Majorana hortensis Minch. We also aimed to evaluate the antimicrobial activity of these plants against pathogenic Bacillus $s p$ and Listeria Monocytogenes ATCC1297. Data obtained from this study could help to identify the potential essential oils to be applied as food preservatives.

\section{Materials and methods}

Isolation of essential oil portions

Portions (100 g) of each prepared plant material were hydro distilled for $3 \mathrm{~h}$ in a Clevenger type apparatus to isolate the essential oils. The obtained essential oils were dried over anhydrous sodium sulfate. After filtration, they were stored in the dark glass bottles at $-4{ }^{\circ} \mathrm{C}$ until used for further analyses. The following oils were used: Pulicaria gnaphalodes, Ducrosia anethifolia, Trachyspermum copticum, Foeniculum vulgare Mill and Majorana hortensis Minch.

Gas chromatography $(G C)$ and gas chromatography mass spectrometry (GC/MS) analysis

The composition of the volatile constituents was established by gas chromatography-mass spectrometry (GC-MS) Thermo-UFM (Ultra-fast model, Milan, Italy) equipped with flame ionization detector (FID) and a capillary column $\mathrm{Ph}-5$ (nonpolar) $(10 \mathrm{~m} \times 0.1$ $\mathrm{mm}$, film thickness $0.4 \mu \mathrm{m}$, the inner surface covered with stationary phase material, dimethyl siloxane phenyl $5 \%$ ). Helium was used as a carrier gas with inlet pressure of $0.5 \mathrm{ml} / \mathrm{min}$. Column temperature was held at $60{ }^{\circ} \mathrm{C}$ for $3 \mathrm{~min}$, programmed to $285^{\circ} \mathrm{C}$ at the rate of $80{ }^{\circ} \mathrm{C} / \mathrm{min}$. Detector and injector chamber temperatures were $280{ }^{\circ} \mathrm{C}$. GC-MS analyses were carried out on a Varian 3400 GC-MS system connected to a mass spectrometer model Saturn II, using an ion trap system having ionization energy of $70 \mathrm{eV}$, with a semi-polar DB-5 column, with dimensions of $30 \mathrm{~m} \times 0.25 \mathrm{~mm}$, and a film thickness $0.25 \mu \mathrm{m}$. Gas pressure was 35 pounds per square inch, column temperature was 40 to $250{ }^{\circ} \mathrm{C}$ with a rate of increase of $4{ }^{\circ} \mathrm{C} / \mathrm{min}$, and the injection chamber temperature and the transfer line were set at $260{ }^{\circ} \mathrm{C}$ and $270{ }^{\circ} \mathrm{C}$, respectively. The carrier gas was helium with a linear velocity of $31.5 \mathrm{~cm} / \mathrm{s}$. A scan time of $1 \mathrm{~s}$ with a mass range of 40-300 amu was used. The components of each oil were identified by comparison of their retention indices (RI) relative to n-alkenes (C7- C25) and confirmed by comparing their mass spectra with those of authentic samples or with data already available in the literature. The quantification of the volatile compounds was performed by GC-MS peak area normalization method using a Shimadzu C-R4AChromatopac without any correction factor (15).

Antimicrobial assay

Agar gel disk diffusion test, minimum inhibitory concentration (MIC) and minimum bactericidal concentration (MBC) were used in this study.

Microorganisms

Bacillus cereus, Bacillus sphericus, Bacillus antheracoid, Bacillus coagulance, Bacillus subtlis 
and Listeria monocytogenes ATCC 1297 were obtained from the School of Veterinary Science of Shiraz University.

\section{Disk diffusion susceptibility}

Antibacterial Susceptibility Assay Muller-Hinton Broth (MHB, Merck) medium was used to grow the test isolates for $22 \mathrm{~h}$ at $37{ }^{\circ} \mathrm{C}$. Final bacterial numbers were standardized to $1 \times 10^{6} \mathrm{cfu} / \mathrm{ml}$. A total of $0.1 \mathrm{ml}$ of bacterial suspension was poured into each plate containing Muller-Hinton Agar. The surface culture was prepared by sterile L shape pipet Pasteur and allowed to remain in contact for $1 \mathrm{~min}$. Thereafter, a $5 \%$ concentration of each plant essential oils was prepared. The sterile filter paper disks (6-mm diameter) were placed on the cultures and $24 \mathrm{~h}$ after incubation at $37{ }^{\circ} \mathrm{C}$ the zone diameter of inhibition (ZDI) was measured in $\mathrm{mm}$. In order to determine the sensitivity of each bacterial species tested, tetracycline was used as a positive control standard. All the experiments were performed in triplicate (1).

\section{Determining the $M I C$ and $M B C$}

For each essential oil, a set of 9 sterile test tubes was used. The stock solutions $(500 \mathrm{mg} / \mathrm{ml})$ were further diluted in a 2-fold serial dilution to obtain the following concentrations: 250, 125, 62.5, 31.25, $15.625,7.8125,3.91,1.95$, and $0.98 \mathrm{mg} / \mathrm{ml}$. One test tube as a negative control and tetracycline as a
Positive control was used. An aliquot of $1 \mathrm{ml}$ of the bacterial suspension was inoculated into each tube. The negative control tubes were inoculated with the same quantity of extracts. All tubes were incubated at $37{ }^{\circ} \mathrm{C}$ for $24 \mathrm{~h}$. The lowest concentration that did not permit any visible growth when compared with the control was considered as the minimum inhibitory concentration (MIC). The contents of all tubes that showed no visible growth were cultured on Muller Hinton agar and incubated at $37{ }^{\circ} \mathrm{C}$ for $24 \mathrm{~h}$. The MIC was considered as the lowest concentration that could not produce a single bacterial colony and the MBC was defined as the lowest concentration of the extract at which $99.9 \%$ of the inoculated microorganisms were killed (16).

\section{Statistical analysis}

In order to determine whether there is a statistically significant difference among the obtained results from zone inhibition assays, MIC and MBC average analyses were carried out using the SPSS V16.0 statistical software package. The differences between any means were tested by the Duncan test and the results were considered significant when $\mathrm{P}<0.05$.

\section{Results}

Chemical composition of the EOs

The main constituents of the studied essential oils are presented in Table 1.

Table 1. Chemical composition (\%) of identified compounds in the tested essential oils determined by gas chromatography- mass spectrometry.

\begin{tabular}{|c|c|c|c|c|}
\hline Plant & Compounds & $(\%)$ & RI & RT(min) \\
\hline \multirow{5}{*}{ T. copticum } & $\beta$-Pinene & 0.63 & 989.52 & 1.5 \\
\hline & Myrcene & 0.40 & 1010.10 & 1.52 \\
\hline & p-Cymene & 22.45 & 1049.25 & 1.6 \\
\hline & 8 -terpinen & 35.45 & 1081.93 & 1.67 \\
\hline & Thymol & 38.97 & 1309.99 & 2.11 \\
\hline \multirow{7}{*}{ F. vulagre } & $\alpha$-Pinene & 0.76 & 956.99 & 1.42 \\
\hline & $\beta$-Pinene & 0.55 & 989.52 & 1.5 \\
\hline & p-Cymene & 0.34 & 1044.47 & 1.59 \\
\hline & Limonene & 6.06 & 1058.73 & 1.62 \\
\hline & Fenchone & 11.15 & 1121.99 & 1.76 \\
\hline & Methyl Chavicol & 3.79 & 1232.62 & 1.96 \\
\hline & e-Anethole & 76.80 & 1324.80 & 2.14 \\
\hline \multirow{10}{*}{ M. hortensis } & $\beta$-Pinene & 2.46 & 989.52 & 1.5 \\
\hline & Limonene & 0.29 & 1058.73 & 1.62 \\
\hline & 1,8 cineole & 0.94 & 1063.43 & 1.63 \\
\hline & Linalool & 86.44 & 1113.27 & 1.74 \\
\hline & geranyl acetate & 1.17 & 1436.12 & 2.32 \\
\hline & $\beta$-elemene & 1.60 & 1477.11 & 2.39 \\
\hline & e-caryophyllene & 0.61 & 1488.60 & 2.41 \\
\hline & 8-cadinene & 1.49 & 1561.04 & 2.54 \\
\hline & 1,1-di-epi-cubinol & 0.39 & 1693.50 & 2.72 \\
\hline & ten-cadinol & 2.85 & 1712.91 & 2.75 \\
\hline
\end{tabular}




\begin{tabular}{|c|c|c|c|c|}
\hline \multirow{14}{*}{ D. anethifolia } & $\alpha$-Pinene & 3.09 & 956.99 & 1.42 \\
\hline & $\beta$-Pinene & 0.63 & 989.52 & 1.5 \\
\hline & Limonene & 0.51 & 1058.73 & 1.62 \\
\hline & Fenchone & 0.29 & 1121.99 & 1.76 \\
\hline & Camphor & 0.88 & 1172.33 & 1.88 \\
\hline & Decanal & 0.48 & 1221.85 & 1.94 \\
\hline & Cis-Chrysanthenyl acetate & 72.28 & 1289.91 & 2.07 \\
\hline & e-Anethole & 4.33 & 1314.95 & 2.12 \\
\hline & trans-Pinocarvyl acetate & 2.11 & 1329.69 & 2.15 \\
\hline & Carvacrol & 2.52 & 1339.41 & 2.17 \\
\hline & Cis-Pinocarvyl acetate & 0.46 & 1372.72 & 2.24 \\
\hline & Aromadendrene & 1.19 & 1471.33 & 2.38 \\
\hline & $\alpha$ - Humulene & 0.37 & 1488.60 & 2.41 \\
\hline & $\beta \overline{\beta \text {-eudesmol }}$ & 8.79 & 1680.44 & 2.7 \\
\hline \multirow{27}{*}{ P. gnaphalodes } & $\alpha$-Pinene & 1.62 & 956.99 & 1.42 \\
\hline & p-Cymene & 1.66 & 1054.01 & 1.61 \\
\hline & Limonene & 1.80 & 1058.73 & 1.62 \\
\hline & 1,8 -cineole & 14.12 & 1063.43 & 1.63 \\
\hline & Terpinolene & 0.26 & 1095.52 & 1.7 \\
\hline & Linalool & 1.13 & 1108.87 & 1.73 \\
\hline & cis-p-menth-2-en-1-ol & 2.87 & 1130.61 & 1.78 \\
\hline & Chrysanthenone & 1.98 & 1151.76 & 1.83 \\
\hline & Cis-chrysanthenone & 2.56 & 1176.38 & 1.89 \\
\hline & Terpinen-4-ol & 4.25 & 1221.85 & 1.94 \\
\hline & $\alpha$-Terpineol & 5.79 & 1232.62 & 1.96 \\
\hline & Nerol & 0.53 & 1259.05 & 2.01 \\
\hline & Thymol & 0.30 & 1294.96 & 2.08 \\
\hline & Carvacrol & 4.54 & 1314.95 & 2.12 \\
\hline & $\alpha$-cubeben & 3.21 & 1363.31 & 2.22 \\
\hline & $\beta$-cubeben & 1.67 & 1424.19 & 2.3 \\
\hline & germacrene-D & 1.79 & 1528.08 & 2.48 \\
\hline & Alpha-murolene & 3.08 & 1544.66 & 2.51 \\
\hline & 8-cadinene & 10.98 & 1566.46 & 2.55 \\
\hline & Trans-Calamene & 0.75 & 1582.58 & 2.58 \\
\hline & $\alpha$-calacorene & 1.58 & 1613.66 & 2.6 \\
\hline & Elemicine & 1.33 & 1633.96 & 2.63 \\
\hline & 1,10-epi-cubenol & 1.24 & 1693.50 & 2.72 \\
\hline & 1 - epi-cubenol & 1.09 & 1700 & 2.73 \\
\hline & Ten-Cadinol & 9.30 & 1712.91 & 2.75 \\
\hline & G-Cadinol & 13.76 & 1725.73 & 2.77 \\
\hline & $\alpha$-Cadinol & 0.97 & 1744.80 & 2.8 \\
\hline
\end{tabular}

The analysis of the components by gas chromatography and gas chromatography mass spectrometry allowed the identification of 63 compounds, accounting for $94.16 \%, 97.93 \%, 97.9 \%$, $99.45 \%$ and $98.24 \%$ of the composition of volatile substances of Pulicaria gnaphalodes, Ducrosia anethifolia, Trachyspermum copticum, Foeniculum vulgare Mill and Majorana hortensis Minch, respectively. The main components of T. ammi EO were thymol $(38.97 \%)$ and 8-terpinene $(35.45 \%)$. The components of $F$. vulgare Mill EO were E-anethole $(76.80 \%)$ and Fenchone $(11.15 \%)$. The major components of EO obtained from $M$. hortensis Minch was linalool $(86.44 \%)$. The main components of $D$. anethifolia were Cis-chrysanthenyl acetate $(72.28 \%)$ and E-anethole (4.33\%). 1, 8-Cineole (14.12\%) and G-cadinol (13.76\%) were the major constituents of $P$. gnaphalodes EO.
Antimicrobial activity of the tested EOs

For evaluation of bacterial susceptibility to herbal agents three standard tests were carried out, including disk diffusion assay, minimum inhibitory concentration and minimum bactericidal concentration. As can be seen in Tables 2-4, the T. copticum essential oil reveals the potential antibacterial activity against all of the tested bacteria with the mean ZDI ranging from 23.66 to $32.66 \mathrm{~mm}$. The Listeria monocytogenes showed the most susceptibility to the essential oil of T. copticum with the ZDI of $32.66 \mathrm{~mm}$ that was more than tetracycline with the ZDI of 30.5 $\mathrm{mm}$ (Table 2). As have been shown in Tables 2-4, the lowest effect of essential oil against bacteria was related to $D$. anethifolia and there was no effect on $B$. subtlis and B. coagulance. The ZDI of T. copticum essential oil against all of the bacteria was more than control group (tetracycline). 
Table 2. The inhibition zone $(\mathrm{mm})$ of selected herbal essential oils against food-borne pathogen bacteria.

\begin{tabular}{lcccccc}
\multicolumn{1}{c}{ Herbal $(\mathrm{EO})$} & B. cereus & B. sphericus & B. anheracoid & B. coagulance & B. subtlis & L. monocytogenes \\
\hline T. copticum & $31.33 \pm 1.15^{\mathrm{c}}$ & $30 \pm 2^{\mathrm{c}}$ & $29 \pm 1.73^{\mathrm{b}}$ & $27.66 \pm 3.78^{\mathrm{c}}$ & $23.66 \pm 0.57^{\mathrm{bd}}$ & $32.66 \pm 6.42^{\mathrm{cd}}$ \\
$\boldsymbol{F}$. vulgare & $15.66 \pm 3.51^{\mathrm{b}}$ & $15.33 \pm 3.05^{\mathrm{ab}}$ & $14 \pm 3.46^{\mathrm{a}}$ & $15.33 \pm 2.30^{\mathrm{b}}$ & $16.66 \pm 4.16^{\mathrm{b}}$ & $16 \pm 3^{\mathrm{a}}$ \\
$\boldsymbol{P}$. gnaphalodes & $0^{\mathrm{a}}$ & $15.33 \pm 1.15^{\mathrm{ab}}$ & $14 \pm 2^{\mathrm{a}}$ & $0^{\mathrm{a}}$ & $0^{\mathrm{a}}$ & $12 \pm 1^{\mathrm{a}}$ \\
$\boldsymbol{D}$. anethifolia & $13.33 \pm 3.05^{\mathrm{b}}$ & $11.33 \pm 1.15^{\mathrm{a}}$ & $17 \pm 5^{\mathrm{a}}$ & $0^{\mathrm{a}}$ & $0^{\mathrm{a}}$ & $19.66 \pm 3.21^{\mathrm{ab}}$ \\
M. hortensis & $15.33 \pm 3.05^{\mathrm{b}}$ & $20 \pm 4^{\mathrm{b}}$ & $16 \pm 2^{\mathrm{a}}$ & $14 \pm 3.46^{\mathrm{b}}$ & $20.66 \pm 4.16^{\mathrm{bc}}$ & $26 \pm 2^{\mathrm{bc}}$ \\
Tetracycline & $18 \pm 4^{\mathrm{b}}$ & $35.33 \pm 6.42^{\mathrm{c}}$ & $29 \pm 2^{\mathrm{b}}$ & $26.66 \pm 4.61^{\mathrm{c}}$ & $18 \pm 3.46^{\mathrm{b}}$ & $30.66 \pm 5.13^{\mathrm{cd}}$
\end{tabular}

Values are mean \pm S.D. of three replicates. Means with different superscripts within the same row are significantly different (p<0.05).

The MIC and MBC values of the leaf essential oils, at different concentrations ranging from $0.98 \mathrm{mg} / \mathrm{ml}$ to

$250 \mathrm{mg} / \mathrm{ml}$, in comparison with the activity of tetracycline has been shown in Tables 3 and 4.

Table 3. MIC (mg/ml) values of essential oil of the selected plants against isolated bacteria.

\begin{tabular}{lcccccc}
\hline Herbal (EO) & B. cereus & B. sphericus & B. antheracoid & B. coagulance & B. subtlis & L. monocytogenes \\
\hline T. copticum & 1.95 & 1.95 & 1.95 & 1.95 & 3.91 & 0.98 \\
$\boldsymbol{F}$. Vulgare & 7.8125 & 7.8125 & 7.8125 & 7.8125 & 7.8125 & 7.8125 \\
$\boldsymbol{P}$. gnaphalodes & 125 & 7.8125 & 7.8125 & 125 & 125 & 15.625 \\
$\boldsymbol{D}$. anethifolia & 7.8125 & 15.625 & 7.8125 & 125 & NO & 3.91 \\
M. hortensis & 7.8125 & 3.91 & 7.8125 & 7.8125 & 3.91 & 1.95 \\
Tetracycline & 7.8125 & 0.98 & 0.98 & 1.95 & 3.91 & 0.98 \\
Control negative & NO & NO & NO & NO & NO & NO \\
\hline
\end{tabular}

NO: No effect

EO: Essential oil

The results of the MBC method (Table 4) are consistent with the results of the disk diffusion test as shown in Table 2. In summary, the essential oil extracted from $T$. copticum showed the highest antibacterial activity for these bacteria while $D$. anethifoliae essential oil had the lowest antibacterial activity.

Table 4. MBC $(\mathrm{mg} / \mathrm{ml})$ values of essential oil of the selected plants against isolated bacteria.

\begin{tabular}{lcccccc}
\hline \multicolumn{1}{c}{ Herbal (EO) } & B. cereus & B. sphericus & B. antheracoid & B. coagulance & B. subtlis & L. monocytogenes \\
\hline T. copticum & 3.91 & 3.91 & 3.91 & 7.8125 & 7.8125 & 3.91 \\
F. Vulgare & 15.625 & 15.625 & 31.25 & 15.625 & 15.625 & 15.625 \\
$\boldsymbol{P}$. gnaphalodes & NO & 31.25 & 62.5 & NO & NO & 31.25 \\
D. anethifolia & 31.25 & 31.25 & 15.625 & NO & NO & 15.625 \\
M. hortensis & 15.625 & 15.625 & 15.625 & 31.25 & 7.8125 & 3.91 \\
Tetracycline & 15.625 & 1.95 & 3.91 & 3.91 & 7.8125 & 3.91 \\
Control negative & NO & NO & NO & NO & NO & NO \\
\hline
\end{tabular}

NO: No effect

EO: Essential oil 


\section{Discussion}

The results of the essential oils extracted from different fresh aromatic plants collected from Borazjan, a city located in Bushehr Province in the south of Iran, have been shown in Table 1. To date, a large number of studies have focused on T. copticum EO and some of them have reported thymol as the main compound $(17,18)$. In the present study, the major components of $T$. copticum EO obtained from Iran were thymol (38.97\%) and 8-terpinen (35.45\%). Similar to our results, Moazeni et al. (2012) reported that the essential oils extracted from Iran ecotypes consisted of 50.07\% thymol (19). It is clear that geographical variation, cultivar differences, the stage of plant growth, preparation process and other factors may influence oil composition both quantitatively and qualitatively (20). Acidic nature of the hydroxyl group in thymol and the involvement of the hydroxyl group in the formation of hydrogen bonds may explain the highest antimicrobial activity (21). Based on current evidence, T. copticum EO can inhibit food-borne pathogenic microorganisms such as Staphylococcus aureus (22), Pseudomonas aeruginos (23), Salmonella sp, Bacillus subtilisu, Aspergillus flavus and Escherichia coli (24). In the present study, T. copticum EO had the strongest antibacterial effect against $L$. monocytogenes (32.66 mm inhibition zone). Detailed data obtained from a previous study indicated that the growth of pathogenic Bacillus cereus (35 $\mathrm{mm}$ inhibition zone) was significantly affected by $T$. copticum EO (24).

Pulicaria gnaphalodes is traditionally used as a flavoring agent in food. The major components of the essential oil of $P$. gnaphalodes obtained from different areas in Mashhad, a city located in Iran, were completely different from our results (13). Also, B. sphericus was more sensitive to $P$. gnaphalodes with the ZDI of 15.33 $\mathrm{mm}$ in comparison to $B$. antheracoid with the ZDI of 14 $\mathrm{mm}$. It has further been reported that the MIC values of $P$. gnaphalodes against Salmonella typhimurium and Staphylococcus aureus were 0.2 and $0.1 \mathrm{v} / \mathrm{v}$, respectively (25).

Verma et al. (2010) showed that M. hortensis has two chemotypes, including terpinen-4-ol and cis-Sabinene hydrate (26). In a research conducted by Verma et al. (2010) the main constituents of M. hortensis EO were ZSabinene hydrate (31.81), terpinen-4-ol (22.02) and (E)Sabinene hydrate (27). The main components of the EO in the present study were Linalool $(86.44 \%)$, ten-cadinol $(2.85 \%)$ and $\beta$-pinene $(2.46 \%)$. These differences in chemical compositions of the oils could be attributed to the effect of environment on the plants (28). Investigations showed that $M$. hortensis EO can inhibit food-borne pathogenic microorganisms such as Staphylococcus aureus $(22 \mathrm{~mm})$ and Enterobacter spp $(15 \mathrm{~mm})(29)$. M. hortensis showed that EO was more active than P.gnaphalodes against all tested pathogenic bacteria. The higher antibacterial activity of $M$. hortensis is possibly related to the high amount of Linalool that has been reported to possess antibacterial properties.

The components of $F$. vulgare EO in our study were eAnethole (76.80\%), Fenchone (11.15\%) and Limonene $(6.06 \%)$ which is relatively similar to $F$. vulgare composition from Pakistan (30). Dua et al. (2013) reported that the ZDI of $F$. vulgare against Staphylococcus aureus and Bacillus pumilus were 11.17 and $12.67 \mathrm{~mm}$, respectively (31). The growth ZDI in the presence of $F$. vulgare $\mathrm{EO}$ seeds was $15.66 \mathrm{~mm}$ for $B$. cereus, $15.33 \mathrm{~mm}$ for B.sphericus, $14 \mathrm{~mm}$ for B. antheracoid, $15.33 \mathrm{~mm}$ for B. coagulance, $16.66 \mathrm{~mm}$ for $B$. subtlis and $16 \mathrm{~mm}$ for $L$. monocytogenes. However tetracycline was more efficient with the growth ZDI of $18-35.33 \mathrm{~mm}$.

$\mathrm{N}$-decanal (70.1\%), $\alpha$-pinene $(12.4 \%)$ and dodecanal $(5.4 \%)$ are vastly utilized in the industrial companies as major components of essential oils. N-Decanal is used in fragrances and flavorings (32). The main components of $D$. anethifolia in this study were cis-chrysanthenyl acetate $(72.28 \%)$, $\beta$-eudesmol (8.79\%), and e-Anethole $(4.33 \%)$. There is also an interesting similarity between our study and the study conducted by Sohrabi et al. (2016) regarding two main components including 1, 8cineole $14.12 \%$ and G-Cadinol $13.76 \%$ (33). Biological activities such as antimicrobial, antibacterial and antianxiety effects have been reported for $D$. anethifolia (34). The growth ZDI in the presence of $D$. anethifolia EO seeds was $13.33 \mathrm{~mm}$ for $B$. cereus, $11.33 \mathrm{~mm}$ for $B$. sphericus, $17 \mathrm{~mm}$ for $B$. antheracoid, 0 for $B$. coagulance, 0 for $B$. subtlis and $19.66 \mathrm{~mm}$ for $L$. monocytogenes, although tetracycline showed to be more efficient with the growth ZDI of $18-35.33 \mathrm{~mm}$.

\section{Conclusion}

In conclusion, the essential oils extracted from medicinal plants in this study have potential antibacterial activities against the bacteria strains. Our results support the use of these plants in traditional medicine and suggest that some of the plant essential oils possess compounds with good antibacterial properties that can be used as antimicrobial agents in the search for new drugs.

\section{Acknowledgements}

The authors are grateful to biotechnology laboratory technician of Persian Gulf University for valuable technical assistance.

\section{Author Contributions}

The present study was funded by HH and NGH. HH and NGH were also involved in the collection of data, statistical analysis and drafting of the manuscript. Gas chromatography (GC) analysis well done by MA K. MAKand FE read and approved the final manuscript.

\section{Conflict of Interest}

The authors declare that they have no competing interests. 


\section{References}

1. Boskovic M, Zdravkovic N, Ivanovic J, Janjic J, Djordjevic J, Starcevic M, et al. Antimicrobial activity of thyme (Tymus vulgaris) and oregano (Origanum vulgare) essential oils against some food-borne microorganisms. Procedia Food Sci. 2015; 5:1821. PMID: 15000954

2. Sofos JN. Challenges to meat safety in the 21 st century. Meat Sci. 2008; 78(1-2):3-13. PMID: 22062090

3. Kadhem HS, AL-Mathkhury HJM. Inhibitory effect of menthol extracted from Mentha rubra on methicillin-resistant Staphylococcus aureus. Worl Exp Bioc. 2015; 3(2):150-54.

4. Sokovic M, Glamoclija J, Marin PD, Griensven LJLDV Antibacterial effects of the essential oils of commonly consumed medicinal herbs using an in vitro mode. Molecules. 2010; 15(11): 7532-46. PMID: 21030907

5. Calsamiglia S, Busquet M, Cardozo PW, Castillejos L, Ferret A. Invited review: essential oils as modifiers of rumen microbial fermentation. J Dairy Sci. 2007; 90(6):2580-95. PMID: 17517698

6. Busatta C, Mossi AJ, Rodrigues MRA, Cansian RL, De Oliveira JV. Evaluation of Origanum vulgare essential oil as antimicrobial agent in sausage. Braz J Microbiol. 2007; 38(4):6106.

7. Özkalp B, Sevgi F, Özcan M, Özcan MM. The antibacterial activity of essential oil of oregano (Origanum vulgare L.). J Food, Agri \& Enviro. 2010; 8(2):272-4.

8. Bendiabdellah A, Amine Dib MEI, Meliani N, Muselli A, Nassim D, Tabti B, Costa J. Antibacterial activity of daucus crinitus essential oils along the vegetative life of the plant. J Chem. 2013; 7.

9. Amiri MS, Joharchi MR. Ethnobotanical knowledge of Apiaceae family in iran : a review. Avicenna J phytomed. 2016; 6(6):621-35. PMID: 28078243

10. Singla P, Vasudeva N. Pharmacognostical and quality control parameters of Origanum majorana Linn. Stem and root. World J Pharm Pharm Sci. 2014; 3(6):1428-37.

11. Verma RS. Aroma profile of Majorana hortensis as influenced by harvesting height in northern india. Chem Bull "Politehnica" Univ Timisoara. 2010; 55(69):9-11.

12. Al-hajj NQM, Wang HX, Ma C, Lou Z, Bashari M, Thabit R. Antimicrobial and antioxidant activities of the essential oils of some aromatic medicinal plants (Pulicaria inuloides-Asteraceae and Ocimum forskolei-Lamiaceae). Trop J Pharm Res. 2014; 13(8):1287-93

13. Bashi DS, Ghani A, Asili J. Essential oil composition of Pulicaria gnaphalodes (Vent.) Boiss. Growing in iran. J Essent Oil Bear Plants. 2013; 16(2):252-6.

14. Khani A, Asghari J. Insecticide activity of essential oils of Mentha longifolia , Pulicaria gnaphalodes and Achillea wilhelmsii against two stored product pests, the Flour beetle, Tribolium castaneum, and the cowpea weevil , Callosobruchus maculatus. J Insect Sci. 2012; 12 (73):1-10

15. Delnavazi MR, Tavakoli S, Rustaie A, Batooli H, Yassa N. Antioxidant and antibacterial activities of the essential oils and extracts of Dorema ammoniacum roots and aerial parts. Res J Pharmacogn. 2014; 1(4):11-8.
16. Aboaba OO, Smith SI, Olude FO. Antibacterial effect of edible plant extract on Escherichia coli 0157: H7. Pakistan J Nut. 2006; 5: 325-327.

17. Gandomi H, Abbaszadeh S, Jebellijavan A, Sharifzadeh A. Chemical constituents, antimicrobial and antioxidative effects of Trachyspermum ammi essential oil. J Food Process Preserv. 2013:1-6.

18. Rasooli I, Fakoor MH, Yadegarinia D, Gachkar L, Allameh A, Rezaei MB. Antimycotoxigenic characteristics of Rosmarinus officinalis and Trachyspermum copticum L. essential oils. Int $\mathbf{J}$ Food Microbiol. 2008; 122:135-9.

19. Moazeni M, Saharkhiz MJ, Hosseini AA. In vitro lethal effect of ajowan (Trachyspermum ammi L.) essential oil on hydatid cyst protoscoleces. Veter Parasitol. 2012; 187(1-2):203-8. PMID: 22245070

20. Partovi R, Khanjari A, Abbaszadeh S, Sharifzadeh A Chemical Composition and Antimicrobial Effect of Five Essential Oils on Pathogenic and Non-Pathogenic Vibrio parahaemolyticus. Nutrit Food Sci Res. 2017; 4(2):43-52.

21. Saei-Dehkordi SS, Tajik H, Moradi M, Khalighi-Sigaroodi F. Chemical composition of essential oils in Zataria multiflora Boiss. from different parts of Iran and their radical scavenging and antimicrobial activity. Food Chem Toxicol. 2010; 48(6):1562-7. PMID: 20332011

22. Vazirzadeh M, Zaboli J, Mohsenzadeh S, Teixeira da Silva JA, Karbalaei-Heidari HR, Robati R. Antibacterial activity of ajowan (Trachyspermum copticum) seed extract. MAPSB. 2013; 7(1): 5455

23. Mahboubi M, Kazempour N. Chemical composition and antimicrobial activity of Satureja hortensis and Trachyspermum copticum essential oil. Iran J Microbiol. 2011; 3(4):194-200. PMID: 22530088

24. Javed S, Shahid AA, Saleem-Haider M, Umeera A, Ahmad R, Mushtaq S. Nutritional, phytochemical potential and pharmacological evaluation of Nigella sativa (Kalonji) and Trachyspermum ammi (Ajwain). J Med Plants Res. 2012; 6:76875. PMID: 268364389

25. Gandomi H, Abbaszadeh S, Rahimikia E, Shariatifar N Volatile organic compound from Pulicaria gnaphalodes and the antibacterial and antifungal properties of its essential oil and aqueous, ethanolic and methanolic extracts. J Food Proc Preser. 2015; 39:2129-34. PMID: 12456

26. Verma RS, Verma RK, Chauhan A, Yadav AK. Changes in the essential oil composition of Majorana hortensis Moench. cultivated in India during plant ontogeny. J Serbian Chem Soc. 2010; 75(4):441-7.

27. Verma R, Sashidhara KV, Yadav A, Naqvi. Essential oil composition of Majorana hortensis (Moench) from subtropical India. Acta Pharma Sci. 2010; 52:19-22.

28. Oroojalian F, Kasra-kermanshahi R, Azizi M, Bassami MR. Phytochemical composition of the essential oils from three Apiaceae species and their antibacterial effects on food-borne pathogens. Food Chem. 2010; 120:765-70.

29. de Oliveira JLTM, Melo Diniz MDF, de Oliveira Lima E, de Souza EL, Trajano VN, Santos BHC. Effectiveness of Origanum vulgare L. and Origanum majorana L. essential oils in inhibiting 
the growth of bacterial strains isolated from the patients with conjunctivitis. Brazilian Arch Biol Technol. 2009; 52(1):45-50.

30. Anwar F, Ali M, Hussain AI, Shahid M. Antioxidant and antimicrobial activities of essential oil and extracts of fennel (Foeniculum vulgare Mill.) seeds from Pakistan. Flavour Fragr J. 2009; 24:170-6.

31. Dua A, Garg G, Mahajan R. Polyphenols, flavonoids and antimicrobial properties of methanolic extract of fennel (Foeniculum vulgare Miller). Europ J Exper Biol. 2013; 3(4):2038.

32. Ashtari R, Omidi M, Heidari M, Abdoli M, Mahdinejad N, Zare AR. Establishment of an efficient callus induction and plant regeneration system in Ducrosia anethifolia (dc.) An important medicinal plant. Trakia J Sci. 2014; 12(2):132-41.
33. Sohrabi F, Kohanmoo MA, Jamali F. Fumigant toxicity of five medicinal plant essential oils against the date Sap beetle, Carpophilus hemipterus (Linnaeus) and identification of their chemical composition. Sci J Agri. 2016; 39(3): 14-24.

34. Shahabipour S, Firuzi O, Asadollahi M, Faghihmirzaei E, Javidnia K. Essential oil composition and cytotoxic activity of Ducrosia anethifolia and Ducrosia flabellifolia from Iran. J Essen Oil Res. 2013; 25(2):160-3. 